\title{
Evaluation of Metribuzin, Prometryn, and Chloramben for Weed Control on Pigeon Peas [ Cajanus cajan (L.) Millsp.]
}

\author{
Luis Almodóvar-Vega and Adalberto Vélez-Báez ${ }^{2}$
}

\begin{abstract}
Herbicides Metribuzin [4-amino-6-tert-butyl-3-(methylthio)-as-triazin-5-(4H)one] at 0.8 and $1.6 \mathrm{~kg} /$ ha active ingredient, Prometryn [2,4-bis (isopropylamino)-6-(methylthio)-s-triazine] at 3.3 and $6.6 \mathrm{~kg}$, and Chloramben [3amino-2,5-dichlorobenzoic acid] at 3.3 and $6.6 \mathrm{~kg} / \mathrm{ha}$ were evaluated for preemergence weed control on pigeon peas during 1976 at Lajas, Puerto Rico, in a Vertisol soil. The yield with Metribuzin at $0.8 \mathrm{~kg} / \mathrm{ha}$ a.i. was similar $(P=0.01)$ to that of the hand-weeded treatment. No statistical differences in yields were observed among the hand-weeded plots, Metribuzin $1.6 \mathrm{~kg} / \mathrm{ha}$ a.i., and the two Prometryn rates. The least effective herbicide was Chloramben at $3.3 \mathrm{~kg} / \mathrm{ha}$, which at the rate of $6.6 \mathrm{~kg}$ was toxic to the crop. Good preemergence weed control was obtained from the other herbicide treatments with no toxicity to the legume. The higher herbicide rate of each compound controlled the weeds better than the lower rate. Metribuzin and Prometryn are in the process of evaluation for registration according to the Environmental Protection Agency regulations.
\end{abstract}

\section{INTRODUCTION}

Total production of pigeon peas [Cajanus cajan (L.) Millsp.] has increased sharply in Puerto Rico since the mid '70s, especially in the southern part of the island. Farm value of the crop has also increased steadily during the last decade ${ }^{3}$. Some reasons for the increase in the acreage planted are the shifting from sugarcane to other crops, the recent introduction of mechanical pickers for harvesting mature-green pigeon pea pods, and the development of cultivars adapted to mechanization. From 1971 to 1975 Almodóvar and coworkers ${ }^{4}$ evaluated a series of unregistered commercial and experimental preemergence herbicides for weed control on the Kaki cultivar in two localities, Isabela and Fortuna Substations. Similarly, at the Central Analytical and Pesticide Laboratories of the Agricultural Experiment Station residue analyses were run on some of the chemicals. No residues of the parent material or metabolites of Metribuzin [4-amino-6-tertbutyl-3-(methylthio)-as-triazin-5-(4H)-

' Manuscript submitted to Editorial Board December 1, 1978.

${ }^{2}$ Assistant Researcher in Weed Science, Crop Protection Department, and Assistant Researcher, Agronomy and Soils Department, respectively, Lajas Substation, Agricultural Experiment Station, University of Puerto Rico, Río Piedras, P.R.

${ }^{3}$ Abrams, R. and Juliá, F. J., Effect of mechanical, cultural, and chemical weed control on yield and yield components of pigeon peas, Cajanus cajan (L.) Millsp., J. Agr. Univ. P. R. 58(4):466-72, 1974.

${ }^{4}$ Unpublished data of work conducted under project H-173 B by L. Almodóvar (leader), F. Juliá, C. Ramos, and C. Sierra. 
one], Prometryn [2,4-bis (isopropylamino)-6-(methylthio)-s-triazine], or Chloramben [3-amino-2,5-dichlorobenzoic acid] were detected at the rates applied.

\section{MATERIALS AND METHODS}

Pigeon pea cv. Kaki was drill seeded on a Vertisol, Fraternidad clay soil, at the Lajas Substation August 3, 1976. A randomized complete block design with four replications was used. Plots were $3.65 \mathrm{~m}$ wide by $6 \mathrm{~m}$ long with four rows $91 \mathrm{~cm}$ apart; plants were thinned to $30 \mathrm{~cm}$ in the row.

Herbicides were sprayed August 4, 1976, with a precision compressed air field plot sprayer set at $2 \mathrm{~kg} / \mathrm{cm}^{2}$, equipped with 8005 Teejet tips ${ }^{5}$, delivering one liter of herbicide preparation per plot.

Treatments were Prometryn at 3.3 and $6.6 \mathrm{~kg} / \mathrm{ha}$ a.i., Chloramben at the same rates, Metribuzin at 0.8 and $1.6 \mathrm{~kg} / \mathrm{ha}$, handweeded, and nonweeded check plots.

The experiment was overhead irrigated August 5. Furrow irrigation was applied three times during November and December to supplement rainfall. Insects were controlled with three applications of Endosulfan during November and December. Hand-weeded check plots were hoed August 23 and September 13. On the latter date herbicide-treated plots were hand-weeded since chemical activity had been lost.

Inner rows were harvested December 29, 1976, and January 7, 1977, for recording pea-pod yields. Weed control ratings, based on visual observations, were recorded weekly. Weed weights were recorded September 13 .

\section{RESULTS AND DISCUSSION}

\section{CROP YIELDS}

The best herbicide treatment was Metribuzin at $0.8 \mathrm{~kg} / \mathrm{ha}$ a.i. yielding $6,659 \mathrm{~kg}$ of matured green pea-pods per hectare, which was similar in yield to the hand-weeded treatment $(6,334 \mathrm{~kg} / \mathrm{ha})$. No statistical differences at the $1 \%$ level, Duncan's multiple range method, were observed between average yields for the hand-weeded plots, Metribuzin $1.6 \mathrm{~kg} / \mathrm{ha}$, and the two Prometryn rates (6.6 and $3.3 \mathrm{~kg} / \mathrm{ha}$ a.i.). Chloramben treatments were statistically inferior in yield. As expected, the nonweeded treatment was the worst yielder. Table 1 summarizes yields of two pickings.

\footnotetext{
${ }^{5}$ Trade names in this publication are used only to provide specific information. Mention of a trade name does not constitute a warranty of equipment or materials by the Agricultural Experiment Station of the University of Puerto Rico, nor is this mention a statement of preference over other equipment or materials.
} 
WEED CONTROL

Percent weed data were recorded on different dates by visual ratings of herbicide treated plots versus the non-weeded check. To record weed yields, in addition to the visual observations, one late hand-weeding was performed (September 13, 1976) on the preemergence herbicide treatments and the non-weeded plots. The higı,er herbicide rate of each compound gave better weed control than the lower rate. Metribuzin gave

TABLE 1.-Yield totals of two pickings of pigeon-pea pods, cv. Kaki

\begin{tabular}{lcc}
\hline Treatment & Rate & Yield $^{1}$ \\
\hline & $\mathrm{Kg} / \mathrm{h} \alpha$ a.i. & $\mathrm{Kg} / \mathrm{ha}$ \\
Prometryn & 3.3 & $5156.6 \mathrm{~b}$ \\
Prometryn & 6.6 & $5190.2 \mathrm{~b}$ \\
Chloramben & 3.3 & $4484.0 \mathrm{c}$ \\
Chloramben & 6.6 & $3475.1 \mathrm{c}$ \\
Metribuzin & 0.8 & $6658.7 \mathrm{a}$ \\
Metribuzin & 1.6 & $5279.9 \mathrm{~b}$ \\
Hand-weeded & - & $6333.6 \mathrm{ab}$ \\
Non-weeded & - & $2354.1 \mathrm{~d}$
\end{tabular}

'Mean yields followed by the same letter do not differ statistically at $\mathrm{P}=0.01$.

TABLE 2.-Percent weed control based on visual ratings (8/23/76) and weed weight (9/ 13/76)

\begin{tabular}{|c|c|c|c|c|}
\hline \multirow{2}{*}{ Treatment } & \multirow{2}{*}{ Rate } & \multicolumn{2}{|c|}{ Weed control $^{1}$} & \multirow{2}{*}{ Weed weight } \\
\hline & & Broadleaves & Grasses & \\
\hline & $K g / h a$ a.i. & $\%$ & $\%$ & $K g / h a$ \\
\hline Prometryn & 3.3 & 90 & 80 & $6657 \mathrm{bc}$ \\
\hline Prometryn & 6.6 & 97 & 98 & $3811 \mathrm{c}$ \\
\hline Chloramben & 3.3 & 81 & 87 & $12499 \mathrm{~b}$ \\
\hline Chloramben & 6.6 & 96 & 98 & $4921 \mathrm{c}$ \\
\hline Metribuzin & 0.8 & 92 & 95 & $8060 \mathrm{bc}$ \\
\hline Hand-weeded ${ }^{3}$ & - & - & - & 一 \\
\hline Non-weeded & - & 0 & 0 & 22532 a \\
\hline
\end{tabular}

${ }^{1}$ Averages for four replications.

${ }^{2}$ Means followed by the same letter do not differ statistically at $\mathrm{P}=0.01$.

${ }^{3}$ Percent weed control or weights were not considered since plots were weeded previously.

excellent control of grasses and broadleaf weeds. No reduction in crop population or plant vigor was observed with Metribuzin and the Prometryn rates. Chloramben at $6.6 \mathrm{~kg} / \mathrm{ha}$ was toxic to the crop but gave good weed control, except for Ipomoea sp. At the rate of $3.3 \mathrm{~kg} / \mathrm{ha}$ its weed control was deficient. Prevalent weeds in the experimental field were Johnson grass (Sorghum halepense), morning glory (Ipomoea sp.); pig- 
weed (Amaranthus dubius Mart.); junglerice (Echinochloa colonum (L.); and horse purslane (Trianthema portulacastrum L.). Vine-type weeds such as Ipomoea sp. are more troublesome to pigeon peas because they roll up the plant foliage with reduction of photosynthetic activity and also interfere with harvesting. Table 2 presents weed control data percentages based on visual ratings and weed weights $(\mathrm{kg} / \mathrm{ha})$ for two different dates.

On the basis of yield and weed control data, Metribuzin and Prometryn were selected for additional evaluation for seeking registration with E.P.A. under Protocol procedures for special crops.

\section{RESUMEN}

En el 1976 se evaluaron tres herbicidas a dos concentraciones cada uno para el control preemergente de malezas en siembras de gandul, en Lajas, Puerto Rico. Se sembró la variedad Kaki en un suelo Fraternidad arcilloso (Vertisol) usando un diseño experimental de bloques al azar con cuatro repeticiones.

A base de los rendimientos de gandul verde en vaina, el mejor tratamiento fue el de Metribuzin aplicado a razón de $0.8 \mathrm{~kg} / \mathrm{ha}$ i.a. $(6,659 \mathrm{~kg})$ seguido por el desyerbo manual con $6,334 \mathrm{~kg} / \mathrm{ha}$. No hubo diferencias significativas $(P=0.01)$ entre el rendimiento del testigo desyerbado en dos ocasiones y los tratamientos de Metribuzin $1.6 \mathrm{~kg} /$ ha y Prometryn a 6.6 y a $3.3 \mathrm{~kg} / \mathrm{ha}$ i.a., respectivamente.

No se observó toxicidad al gandul o al vigor de la plantas con los diferentes herbicidas usados, con la excepción del Chloramben aplicado a $6.6 \mathrm{~kg} / \mathrm{ha} \mathrm{i.a.}$

Los herbicidas controlaron bien las malezas, con excepción del Chloramben a razón de $3.3 \mathrm{~kg} / \mathrm{ha}$. Este herbicida no controla bien las malezas enredaderas como el bejuco de puerco (Ipomoea sp.). Según lo esperado, el mejor control se obtuvo con las concentraciones dobles de cada uno de los herbicidas usados.

En la actualidad los herbicidas Metribuzin y Prometryn están en proceso de evaluación según los requisitos de la Agencia de Protección Ambiental para poder usarse en el gandul. 